\title{
Affricates in the spontaneous speech of Aromanians in Turia
}

Anastasia V. Kharlamova

General Linguistics Department, Saint-Petersburg State-University, Russia

https://doi.org/10.36505/ExLing-2016/07/0013/000272

\begin{abstract}
This paper deals with the affricate inventory of Aromanian spontaneous speech, using the spoken materials collected in Turia (Greece) in 2002 for the Small Dialectological Atlas of the Balkan Languages. The purpose is to analyse the affricates present in the Turia Aromanian dialect and their development. The texts, which had been previously put down in Romanian-based Aromanian orthography with the help of a native Aromanian speaker, were transcribed using computer programs Sound Forge and Speech Analyzer. The instrumental analysis shows that there are eight affricates to be

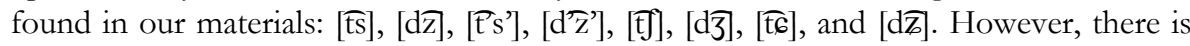
evidence of these sounds - most notably [ts] and [dz] - being in the process of losing their stop phase. On the other hand, there are also instances of an opposite process, namely a fricative phase appearing after $[\mathrm{t}]$. Both processes are fairly well-known typologically and among the Indo-European languages, but there has been previously little to no research on affricate development in Aromanian.

Key words: instrumental phonetics, Aromanian language, Turia, affricates, stops
\end{abstract}

\section{The Aromanian language}

Native speakers of the Aromanian language, a Romance language that belongs to the Eastern Romance subgroup, live in Greece, Albania, Romania, FYRM, Bulgaria and Serbia. Their exact number is unknown mostly for the reason that they usually identify themselves as people of the titular nation of their country (Nedelkov 2009: 247).

Academic research of Aromanian phonetics is mostly done by Romanian dialectologists - according to the Romanian linguistic tradition, Aromanian is a Romanian dialect (Capidan 1932). However, there have previously been no papers dedicated specifically to Aromanian affricates and/or Aromanian spontaneous speech, the only exception being the author's pilot research project (Харламова 2015).

The phonological system of Aromanian is stated to include four affricates - / $\widehat{\mathrm{ts}} /, / \mathrm{d} \widehat{\mathrm{z}} /, / \widehat{\mathrm{T}} /$, and $/ \mathrm{d} \widehat{\mathrm{J}} /$ (Нарумов 2001: 641). The original Romance affricates are a result of palatalization of Latin stops in the position before front-row vowels (Meyer-Lübke 1890: 318-342). Affricates also occur in Slavic, Turkic (Rothe 1957: 62), Greek, and Albanian (Gołab 1984: 40) borrowings. It should be noted that the

ExLing 2016: Proceedings of $7^{\text {th }}$ Tutorial and Research Workshop on Experimental Linguistics, 27 June - 2 July 2016, Saint Petersburg, Russia 
presence of $/ d \bar{z} /$ and $/ d \bar{z} /$ in the consonant system is one of the chief differences between Aromanian and Romanian on the phonological level, for in Romanian these sounds have long lost their stop phase (Meyer-Lübke 1890: 318-342).

\section{Turia Aromanian}

Kranea (Greek), or Turia (Aromanian), is a village with a population of circa 600, located in the Pindos Mountains in Greece, on the border between the administrative districts of Western Macedonia and Thessalia (Бара и Ар. 2005: 16). The inhabitants of the village identify themselves

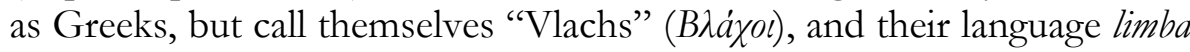
noastrā 'our language', vlähești 'Vlach', and armānești 'Aromanian'. There is a widespread opinion among them that Aromanian can't be written (Бара и Ар. 2005: 17).

The Turia variety of Aromanian is given a full and highly detailed description in (Бара и Ар. 2005). We shall here only summarize the phonetic characteristics of this dialect.

It represents many of the chief features of Southern Aromanian dialect zone, among them the reduction of non-accented /e/ and /o/ into /i/ and /u/, the occurrence non-syllabic / $/$ and $/ \mathrm{i} /$ after final consonants, syncopes, etc (Бара и Ар. 2005).

The recordings of the Turia Aromanians' spontaneous speech that we used in our research are available on a CD attachment to (Бара и $\mathrm{Ap}$. 2005). The list of speakers is given in (Бара и Ар. 2005: 20-22). We mostly used the recording of the speech of Anastasia Pissoni (born in Turia in 1931, housewife).

The first transcription of the analyzed texts had been made by M. Bara, one of the authors of (Бара и Ар. 2005), herself a speaker of Aromanian. However, it was based chiefly on her language intuition, and therefore often reflects her interpretation of the sounds rather than what really was recorded.

Our own transcription was made with the help of two programs developed for phonetic and acoustic research - Sound Forge and Speech Analyzer. Sound Forge was used for building oscillograms and writing down the transcription, while Speech Analyzer was used for spectrograms.

\section{The affricate inventory}

We have found out that the affricate inventory of Turia Aromanian spontaneous speech consists of the following sounds: /t $\widehat{\mathrm{s}} /, / \mathrm{d} \overline{\mathrm{z}} /,\left[\mathrm{t}^{\top} \mathrm{s}^{\prime}\right],\left[\mathrm{d}^{\top} \mathrm{z}\right]$, and $/ \mathrm{t} 5 /$. There are also several doubted occurrences of $/ \mathrm{d} \widetilde{3} /$ and alveolo- 
palatal affricates $[\mathrm{t}]$ and $[\mathrm{d}$ ] $]$. The affricates found in our materials are considered among the most widespread affricate sounds typologically (Berns 2014: 382).

However, sometimes affricates didn't appear in the positions where they ought to have been (according to (Papahagi 1974) and (Бара и Ар. 2005)), instead being replaced by homorganic fricatives. There were other occasions, of [ts] occurring in place of $/ \mathrm{t} /$.

\section{The loss of stop}

The loss of stop in affricates in our materials didn't occur regularly. We have found occurrences of complete change of [ts] and [dz], as well as their palatal equivalents, into fricatives, and of weakened stop in [t]]. There is too little data on the rest of the affricates to draw any conclusions from it.

The change of affricate into a fricative sound occurred usually in short frequent words, most notably ți 'what', and dāsi 'said'. The resulting fricative in place of an alveolar affricate could be $[\mathrm{s}],\left[\mathrm{s}^{\prime}\right],\left[\int\right],[\mathrm{z}]$, or [ $\left.\mathrm{z}^{\prime}\right]$.

In the transcription made by $\mathrm{M}$. Bara, there are 50 occurrences of $d_{s}$ and $94 t$, . Of them, $24 d s$ (about 50\%) and $38 t ⿱ t$ (about 40\%) were found to have lost the stop phase in pronunciation.

As for the weakening stop in [t]], there are no statistics on it for now, mainly because there is of yet no definite scale of stop strength; therefore, we should first set a border between a strong stop and a weak one.

If we look at the facts of phonetical typology, we find that the disappearance of stop phase has been observed or reconstructed in many languages, according to (Kümmel 2007). In (Żygis et al. 2012: 299) it has been suggested that the voiced affricates are more likely to lose their stop phase, due to their complicated articulation.

\section{Affricated [t]}

There are several clear cases of affrication of $[t]$ in the analysed data: 3 occurrences of full affrication and 10 appearances of an audible fricative phase. All of them are recorded before front vowels.

In (Kümmel 2007) this process is mostly found in reconstructions. However, there are two well-known and notable examples of $[\mathrm{t}]$ affrication, one of them occurring in late Latin and influencing the whole subsequent Romance group, and the other being one of the results of the High German consonant shift. 
Therefore, although affrication is not as widely spread as loss of stop phase, it is still not a rare process typologically. Most importantly, it has already taken place once in the history of the Romance languages.

\section{Future research}

Our main perspectives for future research include: first, observation of this dialect's development over the years; second, collection of spontaneous speech data from other Aromanian dialects; third, use of our knowledge of contacts of Aromanian with other languages to better describe and predict its language changes.

\section{References}

Berns, J. 2014. A Typological Sketch of Affricates. Linguistic Typology, 18 (3).

Capidan, Th. 1932. Aromânii. Dialectul aromân. București, Imprimeria națională.

Gołąb, Z. 1984. The Arumanian dialect of Kruševo in SR Macedonia, SFR Yugoslavia. Skopje, Macedonian Academy of Sciences and Arts.

Kümmel M. 2007. Konsonantenwandel: Bausteine zu einer Typologie des Lautwandels und ihre Konsequenzen für die vergleichende Rekonstruktion. Wiesbaden, Reichert Verlag.

Meyer-Lübke, W. 1890. Grammatik der Romanischen Sprachen, Bd. 1. Leipzig, Fues's Verlag.

Nedelkov, J. 2009. The Ethnic Code of the Vlachs at the Balkans. EthnoAnthropoZoom 6, 221-253.

Papahagi, T. 1974. Dicționarul dialectului aromân general și etimologic. Ediția a doua augmentată. Bucuresti: Editura Academiei Republicii Socialiste România.

Rothe, W. 1957. Einführung in die historische Laut- und Formenlehre des Rumänischen. Tübingen, Max Niemeyer Verlag.

Бара М., Каль Т., Соболев А. Н. 2005. Южноарумынский говор села Турья (ПинА). München, Biblion Verlag.

Нарумов, Б. П. 2001. Арумынский язык/Аиалект. In ЖАанова Т. Ю. и Ар. (реА.) 2001, Языки мира. Романские языки, 636-656. Москва, Асаdemia.

Харламова, А. В. 2015. Опыт фонетического анализа арумынской спонтанной речи. In Чердаков А. Н. (ed.), XVIII МежАународная конференция студентовфилологов. Тезисы докладов. Санкт-Петербург, Филологический факультет СПбГУ 